Article

\title{
Analysis of DnaK Expression from a Strain of Mycoplasma fermentans in Infected HCT116 Human Colon Carcinoma Cells
}

\author{
Sabrina Curreli ${ }^{1,2, *}$, Hervé Tettelin ${ }^{3,4}$, Francesca Benedetti ${ }^{1,5}{ }^{(D}$, Selvi Krishnan ${ }^{1}$, Fiorenza Cocchi ${ }^{1,2}$, \\ Marvin Reitz ${ }^{1}$, Robert C. Gallo ${ }^{1,2}$ and Davide Zella ${ }^{1,5, * \mathbb{D}}$
}

1 Institute of Human Virology, University of Maryland School of Medicine, Baltimore, MD 21201, USA; FBenedetti@ihv.umaryland.edu (F.B.); SKrishnan@ihv.umaryland.edu (S.K.); FCocchi@ihv.umaryland.edu (F.C.); MReitz@ihv.umaryland.edu (M.R.); RGallo@ihv.umaryland.edu (R.C.G.)

2 Department of Medicine, University of Maryland School of Medicine, Baltimore, MD 21201, USA

3 Institute for Genome Sciences, Department of Microbiology and Immunology,

University of Maryland School of Medicine, Baltimore, MD 21201, USA; tettelin@som.umaryland.edu

4 Department of Microbiology and Immunology, University of Maryland School of Medicine, Baltimore, MD 21201, USA

5 Department of Biochemistry and Molecular Biology, University of Maryland School of Medicine, Baltimore, MD 21201, USA

* Correspondence: scurreli@ihv.umaryland.edu (S.C.); dzella@ihv.umaryland.edu (D.Z.)

check for updates

Citation: Curreli, S.; Tettelin, H.; Benedetti, F.; Krishnan, S.; Cocchi, F.; Reitz, M.; Gallo, R.C.; Zella, D. Analysis of DnaK Expression from a Strain of Mycoplasma fermentans in Infected HCT116 Human Colon Carcinoma Cells. Int. J. Mol. Sci. 2021, 22, 3885. https://doi.org/10.3390/ ijms 22083885

Academic Editor: Andreas Burkovski

Received: 16 March 2021

Accepted: 7 April 2021

Published: 9 April 2021

Publisher's Note: MDPI stays neutral with regard to jurisdictional claims in published maps and institutional affiliations.

Copyright: (c) 2021 by the authors. Licensee MDPI, Basel, Switzerland. This article is an open access article distributed under the terms and conditions of the Creative Commons Attribution (CC BY) license (https:/ / creativecommons.org/licenses/by/ $4.0 /)$.
Abstract: Several species of mycoplasmas, including Mycoplasma fermentans, are associated with certain human cancers. We previously isolated and characterized in our laboratory a strain of human mycoplasma M. fermentans subtype incognitus (MF-I1) able to induce lymphoma in a Severe Combined Immuno-Deficient (SCID) mouse model, and we demonstrated that its chaperone protein, DnaK, binds and reduces functions of human poly-ADP ribose polymerase-1 (PARP1) and ubiquitin carboxyl-terminal hydrolase protein-10 (USP10), which are required for efficient DNA repair and proper p53 activities, respectively. We also showed that other bacteria associated with human cancers (including Mycoplasma pneumoniae, Helicobacter pylori, Fusobacterium nucleatum, Chlamydia thrachomatis, and Chlamydia pneumoniae) have closely related DnaK proteins, indicating a potential common mechanism of cellular transformation. Here, we quantify dnaK mRNA copy number by RT-qPCR analysis in different cellular compartments following intracellular MF-I1 infection of HCT116 human colon carcinoma cells. DnaK protein expression in infected cells was also detected and quantified by Western blot. The amount of viable intracellular mycoplasma reached a steady state after an initial phase of growth and was mostly localized in the cytoplasm of the invaded cells, while we detected a logarithmically increased number of viable extracellular bacteria. Our data indicate that, after invasion, MF-I1 is able to establish a chronic intracellular infection. Extracellular replication was more efficient while MF-I1 cultured in cell-free axenic medium showed a markedly reduced growth rate. We also identified modifications of important regulatory regions and heterogeneous lengths of $d n a K$ mRNA transcripts isolated from intracellular and extracellular MF-I1. Both characteristics were less evident in $d n a K$ mRNA transcripts isolated from MF-I1 grown in cell-free axenic media. Taken together, our data indicate that MF-I1, after establishing a chronic infection in eukaryotic cells, accumulates different forms of $d n a K$ with efficient RNA turnover.

Keywords: Mycoplasma fermentans; DnaK expression; mRNA; DnaK protein; intracellular localization

\section{Introduction}

The role of certain bacteria associated with human cancers in promoting cell transformation is poorly understood except in the case of $H$. pylori, where a causative relationship with stomach cancer has been observed [1], potentially triggered by reducing p53 activities [2]. M. fermentans (MF) is a bacterium of the Mollicutes class, which lack a cell wall and 
have a reduced genome size [3]. Though most mycoplasmas are extracellular, some invade eukaryotic cells [4-8], colonizing different intracellular compartments [9]. The bacteria subsequently enter a chronic infectious stage, where reduced proliferation and the production of a small number of viable particles are observed [10-13]. Some data indicate that mycoplasmas may facilitate tumorigenesis in humans and in some cases may be directly involved in one or more stages of their cause [14]. In this regard, in vivo infection has been associated with some human cancers, including HIV-seropositive subjects with non-Hodgkin's lymphoma (NHL) [15], prostate cancer [16], and oral cell carcinoma [17]. In addition, in vitro infection of $M$. fermentans subtype incognitus induces chromosomal alterations in both human prostate and murine embryonic cell lines, with the acquisition of malignant properties in mouse and human cells, including loss of anchorage dependency, ability to form colonies in soft agar and tumorigenicity in nude mice [18-20]. Finally, several mycoplasmas (M. fermentans, $M$. arginini, M. hominis, and M. arthritidis) inhibit p53 activity and cooperate with Ras in oncogenic transformation, though the responsible bacterial protein was not identified [21].

DnaK is a member of the human Hsp70 chaperone family and a central component of the bacterial chaperone system [22]. DnaK binds to exposed regions of unfolded or partially folded proteins, ensuring that they achieve their proper functional conformation, and it participates in the assembly of large multi-protein complexes, preventing the formation and precipitation of unstable protein aggregates [23]. We previously demonstrated that DnaK from a strain of M. fermentans subtype incognitus isolated in our laboratory (MF-I1) from an HIV patient binds to human proteins Poly (ADP-Ribose) polymerase 1 (PARP1), central for sensing DNA damage and initiating repair activities, and Ubiquitin carboxylterminal hydrolase 10 (USP10) [24], which promotes activity and stabilization of p53, critical for its anti-cancer functions [25]. We than showed that, upon transfection and expression in human adenocarcinoma cells (HCT116), DnaK reduced PARP-dependent DNA repair activities and p53-dependent anti-cancer responses [24,26]. Phylogenetic amino acid analysis shows that other bacteria associated with human cancers (including certain mycoplasmas, H. pylori, F. nucleatum, and C. thrachomatis) have highly related DnaK proteins, suggesting a possible common mechanism of cellular transformation [24,26].

Bacterial proteins, including DnaK, can be translocated into eukaryotic cells either upon attachment to the cellular membrane or upon invasion $[27,28]$. Thus, it is presumed that DnaK from MF-I1 isolate translocated into cellular compartments could lead to disruption of important cellular pathways. DnaK is known to be expressed by actively proliferating bacteria, and its expression is increased under stress conditions [29-32]. However, little is known about DnaK expression and regulation by mycoplasma upon cellular invasion.

In this study, we quantified DnaK copy number and expression (mRNA) in different cellular compartments following invasion of HCT116 human colorectal carcinoma cells with MF-I1 strain. We also measured the number and replicative ability of viable intracellular bacteria (assessed by CFU assays), as compared to cell-free bacteria. Circularized reverse transcription coupled with PCR (cRT-PCR) and followed by analysis of cloned and sequenced amplified products was used to compare important regulatory regions and heterogeneous lengths of $d n a K$ mRNA transcripts isolated from intracellular mycoplasma and from cell-free particles. We demonstrate that MF-I1 invasion of the eukaryotic cells leads to their chronic infection by viable bacteria with poor replicative capacity, but which still express DnaK. Upon its secretion and accumulation over time in chronically infected cells, this would result in its binding to human proteins, eventually interfering with and reducing the activities of some proteins, as we already demonstrated in the case of PARP1 and p53 [24,26]. 


\section{Results}

2.1. Infection of Human HCT116 Cancer Cells Results in Reduced M. fermentans MF-I1 Replication, Increased Expression of dnaK DNA Copy Number and Detection of Intracellular DnaK

Little is known about the levels of expression and intracellular localization of $\mathrm{My}$ coplasma dnaK during the invasion of eukaryotic cells. We investigated the ability of MF-I1 isolate to invade mammalian cells (HCT116 colon carcinoma) by using a Gentamicin protection assay [33]. Adherent cells were harvested at day 1, day 3, and day 6 following infection by trypsinization followed by multiple PBS washes and QPCR was used to measure intracellular MF-I1 DNA dnaK copy numbers over time in culture. Subsequently, expression of $d n a K$ was quantified in different cell compartments by qRT-PCR and correlated with viable bacteria recovered intracellularly and quantified by CFU analysis. For comparison, viable bacteria of MF-I1 were also quantified in culture supernatants of the same cells (extracellular) and in MF-I1 cultured in McCoy's 5A medium (cell-free, axenic medium). Western Blot analysis was used to confirm and quantify expression of DnaK protein in infected cells.

Intracellular MF-I1 DNA copies per 10,000 detached trypsinized cells increased 3.4fold from day 1 to day 3 post-infection and 11.5-fold by 6 days, reaching a copy number of $9.38 \times 10^{5} \pm 6.19 \times 10^{4} / 10,000$ cells (Figure 1A). The changes were significant $(p=0.003$ and $p=0.0008$, respectively). The amount of MF-I1 in culture supernatants increased 119.5-fold (Figure 1B) from day 1 to day 3 of infection $(p<0.0001)$ and 3329 times after 6 days of infection $(p=0.0002)$, reaching a copy number of $7.69 \times 10^{9} \pm 3.07 \times 10^{8} / \mathrm{mL}$. In contrast, when MF-I1 was grown in McCoy's 5A medium without cells, we observed only a 1.75 -fold increase of MF-I1 from day 1 to day 3 , and only 1.21 -fold $(p=0.1)$ by day 6 , reaching a copy number of $6.69 \times 10^{4} \pm 8.7 \times 10^{3} / \mathrm{mL}$ (Figure 1C). Thus, the amount of MF-I1 isolate grown axenically on day 6 was 100,000 fold lower than that in the supernatant derived from the culture with HCT116 cells, suggesting that the presence of eukaryotic cells provides critical replication factor/s that improve bacterial growth (compare Figure 1B,C).

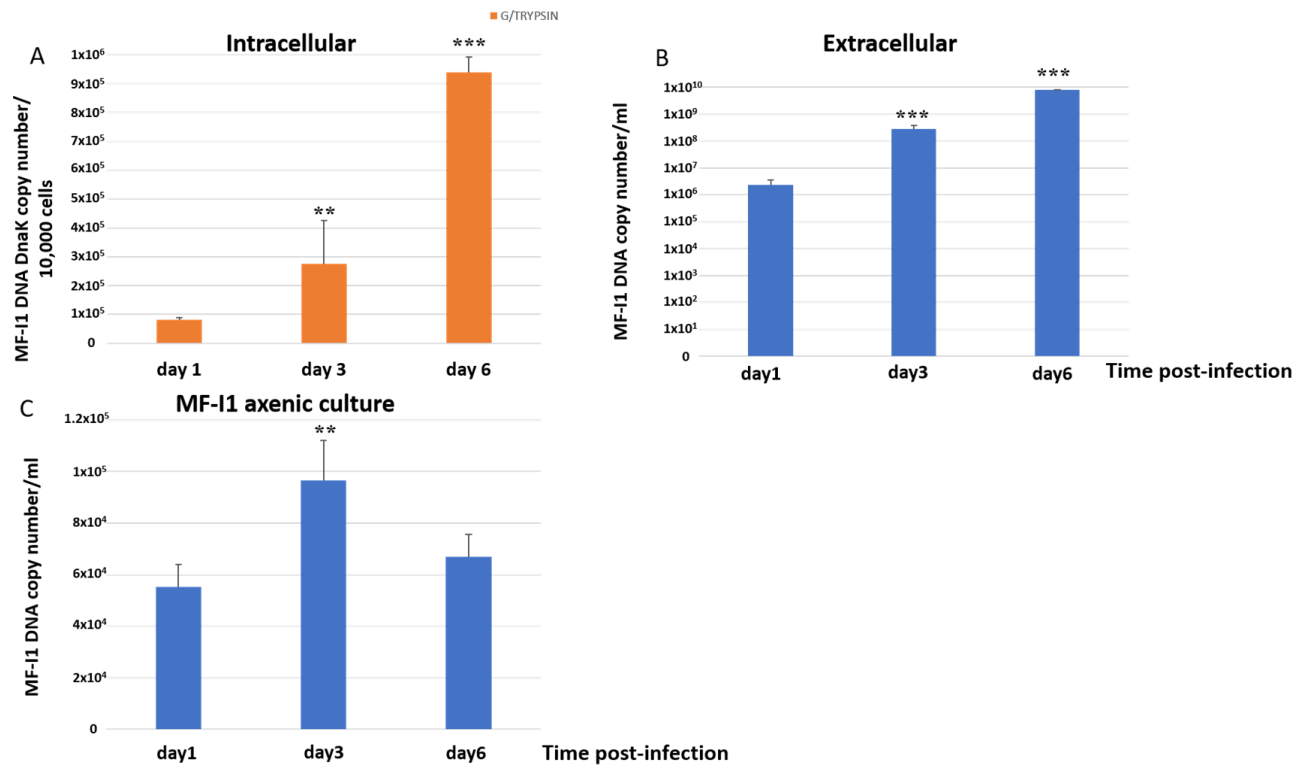

Figure 1. Quantification of $d n a K$ DNA copy number. DNA copy number per 10,000 cells infected trypsinized from MF-I1 infected HCT116 cells (A) and DNA copy number per ml of supernatant from HCT116 infected cells (B) was collected and analyzed at day 1,3, and 6 after infection. (C) DNA from parallel cultures of MF-I1 isolate grown in McCoy's 5A medium, cell-free, axenic medium was collected and analyzed after 1,3, and 6 days of culture post-inoculum. MF-I1 DNA copy number was ascertained by Q-PCR using primers specific for the dnaK gene. MF-I1 DNA levels in the infected cells were normalized to albumin DNA. Data represent the mean values \pm S.E. of samples run in triplicate and are representative of data from three different experiments. The $p$-values were calculated by two sample $t$-test. ${ }^{* *}=p$-value between 0.05 and $0.011^{* * *}=p$-value $<0.01$. 
We next quantified the viable MF-I1 bacteria in the same three culture conditions (Table 1). We observed a 7.6 fold increase in internalized MF-I1 after 3 days of infection $(p=0.002)$, which decreased to 3.2 fold at day 6 (Table 1$)$. These data suggest that the peak of active growth of MF-I1 inside the cells was reached 3 days post-infection and that the increase in $d n a K$ copy number detected by q-PCR represented not only replicating MF-I1, but also defective or non-replicating MF-I1.

Table 1. Invasion of HCT116 cells by Mycoplasma fermentans MF-I1.

\begin{tabular}{cccc}
\hline Time Point & $\begin{array}{c}\text { Internalized MF-I1 } \\
\text { (CFU/10 } \mathbf{6}^{\mathbf{H C T 1 1 6}} \\
\text { Cells) }\end{array}$ & $\begin{array}{c}\text { MF-I1 in Supernatant } \\
\text { from HCT116 Culture } \\
\text { (CFU/mL) }\end{array}$ & $\begin{array}{c}\text { MF-I1 in McCoy's 5A } \\
\text { Medium Axenic } \\
\text { Culture (CFU/mL) }\end{array}$ \\
\hline Day 1 & $8242 \pm 2224$ & $8193 \pm 3461$ & $905 \pm 75$ \\
\hline Day 3 & $62,647 \pm 3512$ & $33,303 \pm 3461$ & $3568 \pm 1275$ \\
\hline Day 6 & $26,371 \pm 596$ & $336,665 \pm 42,757$ & $7874 \pm 903$ \\
\hline
\end{tabular}

To demonstrate the synthesis of DnaK protein, HCT116 cells infected with MF-I1 isolate were collected at day 3 and 6 after the infection together with their corresponding supernatants and were analyzed by Western blot using an antibody specific for bacterial DnaK (see Material and Methods). The presence of DnaK was observed at day 3 and 6 after the infection, both inside the cells and in the supernatants (Figure 2). The amount of recovered protein intracellularly was four times higher at day 3 of the infection compared to the amount of proteins recovered after 6 days of infection (Figure 2B). This is in agreement with the results from the colony assay (Table 1), indicating that the peak of infection in HCT116 cells is reached at day 3. In contrast, the amount of protein observed in the cell's supernatant increased with time (Figure 2A).

In agreement with q-PCR and Western blot, CFUs/mL of MF-I1 in the supernatants from infected HCT116 cells increased 4.1 fold (Table 1 ) from day 1 to day 3 post-infection and 41.1-fold 6 days post-infection. In contrast, the amount of bacteria grown axenically in McCoy's 5A medium after 6 days of culture (in CFUs $/ \mathrm{mL}$ ) was 3-fold less than the amount of MF-I1 grown in the supernatant derived from the HCT116 cell cultures (Table 1). Specifically, the CFU/mL of MF-I1 grown axenically increased only 3.9 fold from day 1 to day 3 of infection and 8.7 times after 6 days of infection, and these increases were not significant ( $p=0.1$ and $p=0.6$, respectively). Our data indicate that the isolated MF-I1 $M$. fermentans strain reaches a steady state replication and number of viable bacteria inside the cells, as previously observed with other bacteria species [10-13]. Our data also indicate that MF-I1 replication rate is more efficient in the supernatant of eukaryotic cells compared to the axenic culture, likely due in part to nutrient factors (e.g., glycerol metabolites and extracellular DNA) released by the cells [34,35]. Although MF-I1 survived in axenic culture, it only did so with a significantly reduced replication rate.

When we analyzed the expression of dnaK RNA in different cellular compartments, we detected increased expression over time, and the majority of RNA was found in the cytoplasm of the cells by day 6 (Figure 3). DNA qPCR analysis confirmed that MF-I1 was indeed mostly localized in the cytoplasm (Figure S1). Interestingly, by comparing these data with the quantification of viable bacteria (compare Figure $1 C$ and Table 1), it is clear that while MF-I1 reached a steady of state level inside the cells, the amount of $d n a K$ RNA was clearly still increasing, indicating active continuous expression. 
A.

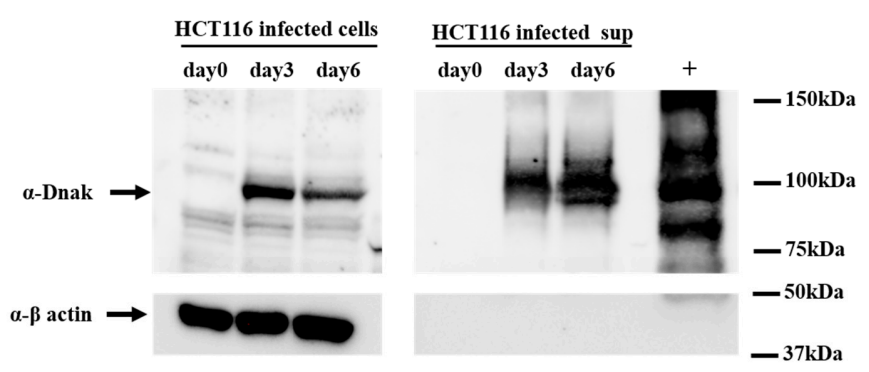

B.

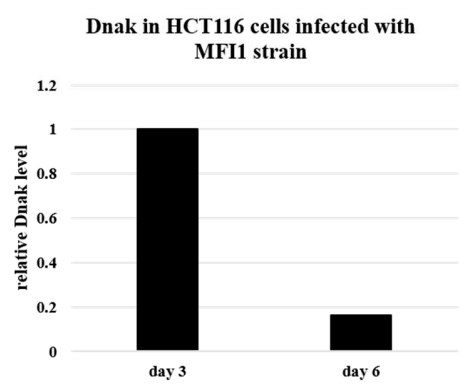

Figure 2. Western blot analysis of DnaK protein in lysates from HCT116 cells infected with MF-I1. Cells were infected with MF-I1 and at day 0, day 3, and day 6 cells and corresponding supernatants were harvested. To ensure the recovery of intracellular Mycoplasma and removal of extracellular mycoplasma from the cells, HCT116 infected cells were treated with gentamicin $400 \mu \mathrm{g} / \mathrm{mL}$ and $0.005 \%$ Triton $\mathrm{x}-100$ two hours after removal of the supernatant before harvesting the cells. (A) Cellular proteins and cleared supernatants were separated by SDS-PAGE and analyzed by Western blot using anti-DnaK and anti- $\beta$ actin antibodies. (B) The relative amount of DnaK protein in HCT116 cells was calculated by using ImageJ software (NIH, Bethesda).

A

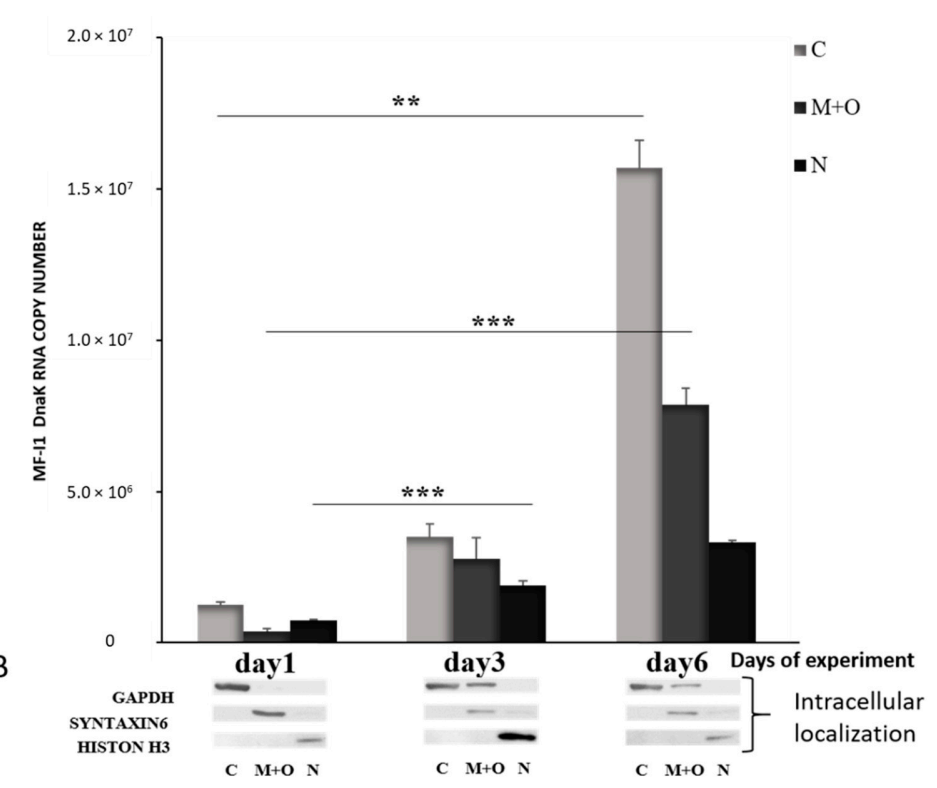

Figure 3. Quantification of dnaK RNA copy number in different intracellular compartments of HCT116 infected with M. fermentans MF-I1. (A): After the indicated days of experiment, RNA was collected from the different cellular compartments, and subjected to qRT-PCR analysis. (B): Western blot was performed to confirm proper fractionation of cell compartments. GAPDH was used as a marker for cytosol, Syntaxin 6 was used to label the membrane compartment and organelles and $\mathrm{H} 3$ for the nucleus. Data represent the mean values \pm S.E. of samples run in triplicate and are representative of data from three different experiments. The $p$-values were calculated by two sample $t$-test. ${ }^{* *}=p$-value between 0.05 and 0.01 ; ${ }^{* * *}=p$-value $<0.01$. Cellular compartments are indicated as follows: C; Cytoplasm; $\mathrm{M}+\mathrm{O}$ : Mitochondria + organelles; N: Nucleus. 


\subsection{Analysis of MF-I1 dnaK Transcripts Exposes the Emergence of Bacteria with Several Mutations in Important Regulatory Regions}

To characterize the termini of the $d n a K$ transcripts and identify their positions with respect to $d n a K$ adjacent genes $r n h B 1$ (located $5^{\prime}$ ), encoding ribonuclease $\mathrm{H}$, and $m g s 1$ (located $3^{\prime}$ ), encoding an ATPase, we performed circularized RT-PCR (cRT-PCR) (Figure S2A) using a set of primers (Table S1) designed to specifically amplify by nested PCR both ends of the RNAs, which were subsequently cloned and sequenced. Since mycoplasmas are self-replicating microorganisms that often infect eukaryotic cells, we decided to compare three in vitro systems, an axenic MF-I1 culture grown in 243 media (the same medium used to produce MF-I1 stocks), MF-I1 grown in HCT116 cultures chronically infected with MF-I1, and an MF-I1 control grown in McCoy's 5A medium without HCT116 cells. Table S3A,B show DNA sequences of 12 clones of $d n a K$ termini derived from MF-I1 axenic cultures in 243 medium (Table S3A) and from HCT116 cells infected with MF-I1 for 6 days (Table S3B). Additionally, in infected HCT116 cultures the $5^{\prime}$ termini of $d n a K$ transcripts were variable and ranged from -50 to -30 nucleotides (nt) upstream from the ATG translation start codon. We also detected some shorter clones that lacked the ATG codon. In contrast, only in one clone out of 12 derived from MF-I1 axenic cultures in 243 medium did we detect a dnaK $5^{\prime}$ terminus (Table S3A,B). No dnaK $5^{\prime}$ or $3^{\prime}$-end sequences were detected from 12 clones analyzed from a parallel MF-I1 axenic culture in McCoy's 5A medium. Absence of detectable dnaK terminal sequences in MF-I1 axenic cultures in McCoy's 5A medium suggests that in the lack of eukaryotic cells McCoy's medium does not support MF-I1 replication and that the number of analyzed clones may have been too limited for detecting transcripts containing $d n a K 5^{\prime}$ and $3^{\prime}$-ends.

As one of five heat shock-induced genes, mycoplasma dnaK contains a regulatory CIRCE element [30,36], which negatively regulates $d n a K$ expression upon interaction with the heat-inducible transcription repressor HrcA (heat regulation at CIRCE), a mechanism that is widespread in bacteria [37]. Using the online program http:/ / emboss.bioinformatics. $\mathrm{nl} /$ cgi-bin/emboss/palindrome (URL accessed on 14 January 2019), we searched for potential CIRCE elements in the upstream region of the dnaK gene of $M$. fermentans. We found an inverted CIRCE-like repeat sequence (TTAGCACT-N 10 -GAGTGCTAA) spanning from nt -75 to -50 upstream the dnaK gene of $M$. fermentans strain JER (CP001995) and a similar sequence (TTAGCACT-N ${ }_{11}$-GAGTGCTAA) at nt -76 to -50 from the dnaK gene of $M$. fermentans strain MF-I1 (ATFG00000000). Another palindrome-like sequence (AAAAAATAATTA$\mathrm{N}_{70}$-TAATTATTTTTT) spanning from $\mathrm{nt}-75$ to -144 upstream $d n a K$ gene was identified in both $M$. fermentans strains. It is of future interest to determine whether both inverted regions interact with the HrcA protein.

The sequences at the $3^{\prime}$-end of $d n a K$ mRNA (Table S3A,B) show a common poly-T termination sequence (TTTTTTAT) +37 to $+44 \mathrm{nt}$ downstream from the TAG stop signal (the positions were identical for M. fermentans MF-I1 and M. fermentans JER). Analysis with an online software program for transcription terminators in bacterial genomes (http:/ / www. softberry.com/berry.phtml?topic=findterm\&group=programs\&subgroup=gfindb, URL accessed on 14 January 2019) predicted a Rho-independent transcription terminator oriented $3^{\prime}$ to $5^{\prime}$, starting $+29 \mathrm{nt}$ downstream from the TAG stop signal and with the length of $42 \mathrm{nt}$ [38]. Most of the clones analyzed from HCT116 cells infected with M. fermentans strain MF-I1 retained the poly-T sequence, while 7 clones of 12 from axenic cultures in 243 medium were shorter and lacked the poly-T termination sequence, but retained the CIRCE element.

Similar to dnaK, the sequences in the rnhB1 $5^{\prime}$-end termini (Table S4A,B) displayed variable lengths, with shorter $5^{\prime}$-ends ranging from -20 to $-55 \mathrm{nt}$ and longer ones ranging from -100 to $-200 \mathrm{nt}$ upstream from the ATG starting codon. One M. fermentans clone from the HCT116 supernatants had $5^{\prime}$ ends at -299 . In contrast, sequences in the rnhB1 $5^{\prime}$-end terminal from $M$. fermentans MF-I1 axenic culture in McCoy's 5A medium displayed only shorter $5^{\prime}$-ends ranging from -29 to $-55 \mathrm{nt}$ (Table S4C). Like dnaK, rnhB1 $3^{\prime}$-end had a common poly-T termination sequence (TTATTTTTTT) in position +85 to $+88 \mathrm{nt}$ 
downstream from the TAG stop signal (Table S5A-C). However, 8 clones out of 12 analyzed from McCoy's 5A medium axenic cultures in Table S5C completely lacked the termination sequence. Therefore, similarly to $d n a K, r n h B 1$ mRNAs appear to be monocystronic when analyzed from either axenic cultures or from HCT116 cells. However, the $5^{\prime}$ terminal region includes the end of the adjacent gene, tagged as MFE_01010 in M. fermentans JER (CP001995), which encodes the COF family HAD hydrolase protein.

Compared to dnaK and rnhB1 end transcripts, we obtained a different result from analyzing $m g s 1$ end transcripts (Tables $\mathrm{S} 6$ and S7A,B). In most clones the RNA started with an ATG start codon (Table S6). However, some clones lacked the origin, suggesting that mgs1 mRNAs can start with either the ATG or from alternative internal promoters. The $m s g 1$ $3^{\prime}$-end of clones derived from $M$. fermentans MF-I1 axenic cultures in 243 medium contained nucleotide sequences ranging from $+124 \mathrm{nt}$ to $+64 \mathrm{nt}$ (Table S7A), while clones derived from HCT116 cells infected with $M$. fermentans MF-I1 contained both longer sequences spanning from $+422 \mathrm{nt}$ to $+135 \mathrm{nt}$ and shorter nucleotide sequences ranging from $+90 \mathrm{nt}$ to $+51 \mathrm{nt}$ (Table S7B). One clone derived from infected HCT116 cells was extremely long $(+1361 \mathrm{nt})$. The long mRNAs included sequences from the adjacent pheS gene, encoding for the phenylalanyl-tRNA synthetase alpha subunit, as well as from part of the following ung gene, encoding uracil-DNA glycosylase, and suggesting that mgs1 together with pheS and ung can be transcribed as multicistronic mRNAs (Table S7B). Only 2 shorter nucleotide sequences ranging from $+82 \mathrm{nt}$ to $+75 \mathrm{nt}$ were detected in $m s g 13^{\prime}$-end clones derived from M. fermentans MF-I1 axenic cultures in McCoy's 5A medium (Table S7C), while the remaining 10 clones lacked the $m s g 13^{\prime}$-end.

Polyadenylation degradation intermediates were not detected in dnaK RNAs, nor in the $d n a K$-adjacent genes $r n h B 1$ and $m g s 1$, in agreement with a previous report for M. gallisepticum [39], suggesting that Mycoplasma mRNA is not polyadenylated.

2.3. M. fermentans MF-I1 Strain dnaK mRNA Length Analysis Reveals Presence of Several Types of Transcripts

Bacteria express different species of RNA transcripts from a single gene [40], and our finding of some $d n a K$ mRNAs clones lacking the ATG start codon at the $5^{\prime}$-end (Table S3) prompted us to look further at $d n a K$ mRNA expression. We therefore analyzed dnaK mRNA sizes by cRT-PCR. However, in contrast with the previous $5^{\prime}$ and $3^{\prime}$-termini analyses, specific primers were selected to be complementary to the middle region of the RNA transcripts (Figure S2B and Table S2). A total of 121 clones were analyzed, including 40 clones derived from MF-I1 axenic cultures in 243 medium, 41 from MF-I1-infected HCT116 cells, and 40 from MF-I1 axenic cultures in McCoy's 5A medium. Figure 4 shows a schematic representation of the obtained sequences, and Figure $\mathrm{S} 3$ a multiple sequence alignment.

Sequence alignments revealed extensive length variation compared to the expected size of MF-I1 dnaK mRNA. Specifically, the $3^{\prime}$ terminus was frequently complete, including the terminal hairpin stretch $(+1404)$ in 25 sequences (out of 41) derived from infected HCT116 cells and 24 sequences from the MF-I1 cell-free culture in 243 (out of 40) (Figure 4 and Figure S3), while only 6 sequences contained the hairpin stretch in MF-I1 axenic growth in McCoy's 5A medium. Surprisingly, most of the sequences were truncated at the $5^{\prime}$-end. Only 5 sequences, including 4 originating from the MF-I1 axenic culture in 243 medium and 1 from infected HCT116 cells, consisted of mature full-length transcripts that started between -37 and $-30 \mathrm{nt}$ before the ATG start codon (therefore including the $d n a \mathrm{~K}$ promoter region), in agreement with the data from the $d n a K 5^{\prime}$-end analysis (Table S3A,B). No complete sequence was detected in MF-I1 axenic cultures in McCoy's 5A medium. Six clones from MF-I1 cell-free cultures in 243, 7 from infected HCT116 cells, and 1 from MF-I1 axenic cultures in McCoy's 5A medium included sequences upstream from the ATG start codon, but were truncated at the $3^{\prime}$-end. 


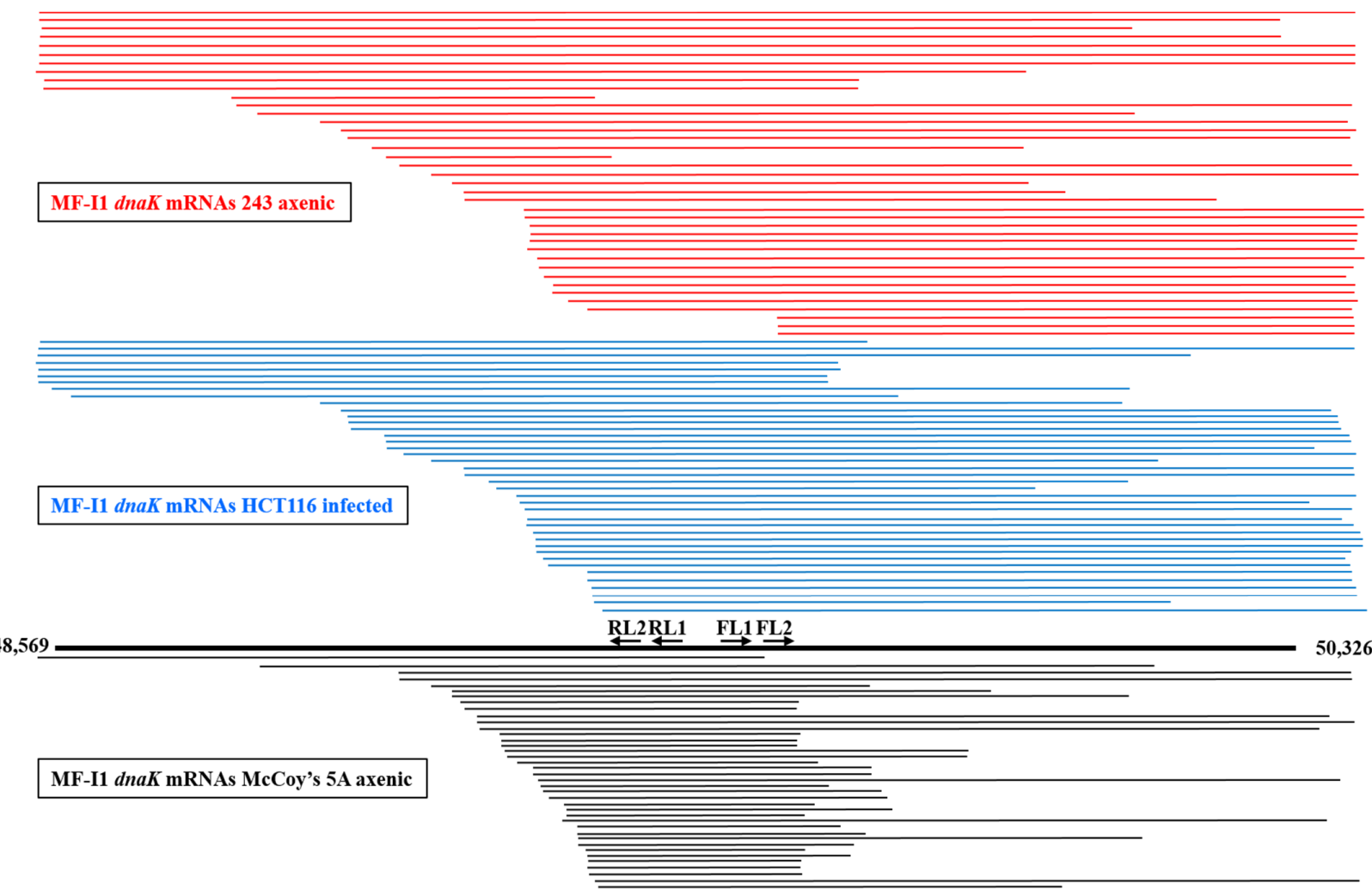

Figure 4. Schematic representation of $d n a K$ RNA length obtained by cRT-PCR analysis. Mycoplasma dnaK mRNA lengths are indicated. The dnaK gene with the ATG start and TAA terminal codons is represented by the thick black line in the bottom. Primer pairs FL1/RL1 and FL2/RL2 used for CRT-PCR are also represented. Horizontal lines representing the cDNAs obtained by cRT-PCR technique are drawn to scale. The top lines in red represent the sequences derived from $d n a K$ RNAs from the MF-I1 axenic culture in 243 medium, middle lines in blue represent sequences derived from dnaK RNAs from HCT116 cells infected with MF-I1, and the bottom lines in black represent the sequences derived from dnaK RNAs from the MF-I1 axenic culture in McCoy's 5A medium. Numbers indicate the nucleotide position of the clone sequences, according to the sequence in GenBank accession (ATFG00000000) comprising the complete M. fermentans MF-I1 genome.

All remaining sequences, including 33 derived from HCT116 cells infected with MF-I1, 30 from MF-I1 axenic 243 cultures, and 39 from MF-I1 axenic cultures in McCoy's 5A medium were truncated at the $5^{\prime}$-end. In particular, the transcripts were highly heterogeneous, but could be aligned in a staircase-like pattern. However, while the remaining 30 sequences derived from MF-I1 axenic cultures in 243 medium (including those beginning from +218 and +772 nt downstream from the ATG start codon) showed a staircase-like pattern, the 33 mRNA sequences derived from HCT116 cells infected with MF-I1 showed a staircase-like pattern that included shorter sequences beginning from +407 and $+783 \mathrm{nt}$ after the ATG start codon. The sequences with a staircase-like pattern were even shorter in the 39 mRNA sequences derived from MF-I1 axenic culture in McCoy's 5A medium, beginning from +517 and $+782 \mathrm{nt}$ after the ATG start codon. Additionally, most of the mRNAs derived from MF-I1 axenic culture in McCoy's 5A medium (34 clones out of 40) were truncated at the $3^{\prime}$-end, especially at positions between +1035 and $+1183 \mathrm{nt}$ after the ATG start codon, while fewer mRNA sequences derived from both MF-I1 cell-free 243 culture and HCT116 cells infected with MF-I1 (16 clones for both) were randomly truncated at the $3^{\prime}$-end (Figure 4 and Figure S3).

These newly identified $5^{\prime}$-end truncated $d n a K$ mRNA sequences are likely the result of a $5^{\prime}$-end RNA decay process, previously observed in Gram-positive and -negative bacteria [41,42]. To this regard, we observed that $5^{\prime}$-end truncated dnaK mRNAs were similarly enriched in MF-I1 cell-free 243 culture and in infected HCT116, while both $5^{\prime}$ and $3^{\prime}$-end dnaK mRNAs were exceedingly truncated in MF-I1 axenic cultures in McCoy's 5A 
medium. This would likely indicate that MF-I1 RNA turnover is more rapid and efficient during infection of eukaryotic cells and axenic growth in nutrient-rich 243 medium than during free bacterial growth in McCoy's 5A medium.

\subsection{Bacteria Grown in Different Conditions Show Differences in dnaK mRNA and Its Internal Promoter}

To find out whether $5^{\prime}$-end truncated $d n a K$ mRNA sequences represented nascent mRNAs originating from the alternative internal promoters, we looked for dnaK internal promoter/s. Using the web server http:/ / www.softberry.com/berry.phtml?topic=bprom\& group=programs\&subgroup=gfindb (URL accessed on 14 January 2019), we identified four putative dnaK promoters, shown in Table 2. Promoter 1 spanned from nt -173 to -145 upstream from the ATG start codon of $d n a K$. This promoter was also upstream from the inverted CIRCE-like repeat sequence located from nt -76 to -50 upstream from the $d n a K$ gene of MF-I1, as reported above in this paper. The three remaining potential promoters were located within the $d n a K$ gene. Promoter 2 spanned from nt +197 to +227 downstream from the ATG start codon of $d n a K$ and promoter 3 spanned from nt +617 to +647 . Promoter 4 was quite far from the ATG start codon of $d n a K$ (Table 2) and only $552 \mathrm{nt}$ distant from the dnaK stop codon.

Table 2. Putative MF-I1 dnaK promoters.

\begin{tabular}{ccc}
\hline dnaK Promoters & $-\mathbf{3 5}$ Box & $-\mathbf{1 0}$ Box \\
\hline Pr. 1 & $(-173)$ TTGATT & $(-153)$ ATTTAATTT \\
\hline Pr. 2 & $(+197)$ TTGCAT & $(+219)$ GGGTACAAA \\
\hline Pr. 3 & $(+617)$ ATGAAA & $(+638)$ TGCTAAAAT \\
\hline Pr. 4 & $(+1205)$ TTGAAA & $(+1224)$ TGTTACAAT \\
\hline
\end{tabular}

In parenthesis is indicated the nucleotide distance of the box sequence from the MF-I1 dnaK ATG start codon.

We next used the Blast program (https:/ / blast.ncbi.nlm.nih.gov/Blast.cgi, URL accessed on 14 January 2019) [43] to verify that some $5^{\prime}$-end truncated dnaK mRNAs likely originate from the newly identified potential promoters. We found that promoters 2 and 3 were frequently included in $d n a K$ transcripts, but none of these transcripts identified with cRT-PCR were long enough at their $5^{\prime}$-end to include promoter 1 . Only one transcript from axenic MF-I1 cultures in 243 medium (C25) contained promoter 2 at the origin of the $5^{\prime}$-end truncated $d n a K$ mRNA sequence, although in various sequences promoter 2 was present internally. In contrast, 6 sequences from MF-I1 axenic cultures in McCoy's 5A medium (M3, M8, M12, M29, M31, and M33) and 2 sequences (H13 and H37) from HCT116 chronically infected with MF-I1 for 6 days had promoter 3 localized at the origin of the $5^{\prime}$-end truncated $d n a K$ mRNA sequence. We could not identify promoter 4 in $d n a K$ transcripts because the cRT-PCR amplicons enriched for $d n a K$ mRNAs were limited to the region spanning from $n t+1036$ to the ATG start codon (Table S2). These results suggest that some of the $5^{\prime}$-end truncated $d n a K$ transcripts originate from internal promoters; however, further studies will be necessary to prove the use of the putative dnaK internal promoters in M. fermentans MF-I1.

Analysis of the mRNA sequences from HCT116 cells infected with MF-I1, MF-I1 axenic culture in 243 medium, and MF-I1 axenic culture in McCoy's 5A medium revealed that $41 \%$ and $35 \%$ of $d n a K$ mRNA transcripts from HCT116 infected and MF-I1 axenic cultures in 243 media, respectively, carried mutations, while only $12 \%$ of $d n a K$ mRNA transcripts from MF-I1 axenic culture in McCoy's 5A medium were mutated (Table 3). The majority of the mutated sequences carried single point mutations, with the exception of two frame shift mutations consisting of one deletion in a sequence from HCT116 cells infected with MF-I1 and one insertion in a sequence from an MF-I1 axenic culture in 243 medium. Of the single point mutations, $22 \%$ from HCT116 infected cultures, $21 \%$ from MF-I1 axenic cultures in 243 medium, and 50\% from MF-I1 axenic cultures in McCoy's 
5A medium were synonymous. The remaining single point mutations led to amino acid changes, and in one case resulted in a stop signal. A common single point mutation, consisting of the substitution of A with G at $+1190 \mathrm{nt}$ after the ATG start codon, leading to the substitution of Glu with Gly in position 397 of the dnaK protein, was detected in four sequences from HCT116 infected with M. fermentans MF-I1.

Table 3. Nucleotide position due to mutations in dnaK transcripts from HCT116 infected with MF-I1 (H1 to H41), MF-I1 grown in axenic conditions in 243 medium (C1 to C40) and free bacterial grown in McCoy's 5A medium (M1 to M40). Amino acid changes are indicated in the single point mutations.

\begin{tabular}{|c|c|c|c|c|}
\hline \multirow[t]{2}{*}{ CLONE } & \multicolumn{2}{|c|}{ POINT MUTATIONS } & \multirow[t]{2}{*}{ INSERTIONS } & \multirow[t]{2}{*}{ DELETIONS } \\
\hline & Nucleotide substitution & Amino acid substitution & & \\
\hline H5 & A1190G & Glu397Gly & & \\
\hline $\mathrm{H} 6$ & C1578G & Asn526Lys & & \\
\hline $\mathrm{H} 8$ & A756G & Leu255Leu & & \\
\hline H9 & A1190G & Glu397Gly & & \\
\hline H10 & A1190G & Glu397Gly & & \\
\hline H11 & A1190G & Glu397Gly & & \\
\hline $\mathrm{H} 12$ & G373T, T600C, A1236G & $\begin{array}{l}\text { Ala125Ser, Gly200Gly, } \\
\text { Lys412Lys }\end{array}$ & & \\
\hline H16 & A1488G & Glu483Gly & & \\
\hline H19 & A1512G & Ala504Ala & & \\
\hline $\mathrm{H} 21$ & & & & A1348 (Lys450) \\
\hline $\mathrm{H} 24$ & A1299G & Thr433Thr & & \\
\hline $\mathrm{H} 28$ & T1304C, G1357A & Ile435Thr, Ala453Thr & & \\
\hline H32 & G1321A & Gly441Arg & & \\
\hline H33 & A1714G & Ser572Gly & & \\
\hline H35 & G1471A, A1484G & Glu491Lys, Asn495Ser & & \\
\hline H39 & A1211G & Asn404Thr & & \\
\hline H41 & A1200G & Thr400Thr & & \\
\hline $\mathrm{C} 2$ & A1368G, T1564C & Ile456Met, Val522Ala & & \\
\hline C9 & & & 790G (His264) & \\
\hline $\mathrm{C} 10$ & T648C & Ile216Ile & & \\
\hline $\mathrm{C} 11$ & G4A, C1309T & Pro2Ser, Ala437Thr & & \\
\hline $\mathrm{C} 13$ & C528G & Phe176Leu & & \\
\hline $\mathrm{C} 15$ & $\mathrm{~T} 1263 \mathrm{C}$ & Ala421Ala & & \\
\hline $\mathrm{C} 16$ & G1715A & Ser572Asn & & \\
\hline $\mathrm{C} 20$ & $\mathrm{C} 732 \mathrm{~T}$ & Asp244Asp & & \\
\hline $\mathrm{C} 24$ & A1075G, T1076C & Ile359Ala & & \\
\hline $\mathrm{C} 26$ & A11G, T57C & Glu4Gly, Ala19Ala & & \\
\hline $\mathrm{C} 34$ & A1503C & Lys501Asn & & \\
\hline C35 & C761T, A1396G & Ser254Leu, Thr466Ala & & \\
\hline C37 & A37G & Thr13Gly & & \\
\hline
\end{tabular}


Table 3. Cont

\begin{tabular}{|c|c|c|c|c|}
\hline \multirow[t]{2}{*}{ CLONE } & \multicolumn{2}{|c|}{ POINT MUTATIONS } & \multirow[t]{2}{*}{ INSERTIONS } & \multirow[t]{2}{*}{ DELETIONS } \\
\hline & Nucleotide substitution & Amino acid substitution & & \\
\hline $\mathrm{C} 40$ & C710T & Ala237Val & & \\
\hline M25 & T1062G & Val354Val & & \\
\hline M26 & T1070C & Arg390Arg & & \\
\hline M30 & G632T & Trp211Leu & & \\
\hline M34 & T764G, G765T & Leu259Leu, Val260Phe & & \\
\hline M35 & C1298T & Thr433Ile & & \\
\hline
\end{tabular}

\section{Materials and Methods}

\subsection{Culture of Bacteria}

M. fermentans subtype incognitus (MF-I1) was isolated in 2014 at the Institute of Human Virology from HIV-1 infected cell supernatants [24] and grown in 243 medium containing heart infusion broth (BD Biosciences, San Jose, CA, USA) supplemented with $20 \%$ heat inactivated horse serum and 10\% yeast extract solution (ThermoFisher Scientific, Waltham, MA, USA), at $37^{\circ} \mathrm{C}$ in aerobic conditions. MF-I1 cultures were harvested in late log phase, collected by centrifugation $\left(30 \mathrm{~min}\right.$ at $10,000 \times g$ at $4{ }^{\circ} \mathrm{C}$ ), and washed three times with PBS before use. Cells were infected with a concentration of $2 \mathrm{CFU}$ (colony forming units)/cell. More details about M. fermentans MF-I1, including data deposition information, were described previously [24].

\subsection{Colony Forming Unit Assay}

Bacterial inoculum was serially diluted in 243 bacterial media derived from ATCC, and $50 \mu \mathrm{L}$ of the dilution was plated in duplicate in $60 \times 15 \mathrm{~mm}$ culture dishes with $2 \times 2 \mathrm{~mm}$ grid culture dishes with $2 \times 2 \mathrm{~mm}$ grid and $21.5 \mathrm{~cm}^{2}$ surface (Fisher Scientific, Hampton, NH, USA). After 7 days routine manual counting was performed by two independent individuals for plates with less than 200 colonies under an inverted microscope. Colony Forming Units (CFU) $/ \mathrm{mL}$ were determined by multiplying the average number of colonies/grids $\times$ number of grids in the plate $(53,750) \times$ the dilution factor $\times 20$ (for $50 \mu \mathrm{L}$ of inoculum).

\subsection{Cells and MF-I1 Infection}

The human cancer cell line HCT116 was obtained from American Type Culture Collection (ATCC CCL-243 ${ }^{\mathrm{TM}}$, Manassas, VA, USA). Cells were maintained in McCoy's 5A medium, supplemented with $10 \%$ fetal bovine serum, $50 \mathrm{IU}$ penicillin, $50 \mu \mathrm{g} / \mathrm{mL}$ streptomycin, and L-glutamine $(290 \mu \mathrm{g} / \mathrm{mL}$ ) (all from ThermoFisher Scientific, Waltham, MA, USA). For time point experiments, HCT116 cells infected with MF-I1 were harvested at day 1, 3, and 6. Parallel cultures of uninfected HCT116 were the negative control. To avoid cell overgrowth in the late time points, flasks of HCT116 cells were split at a 1/4 ratio after $24 \mathrm{~h}$ and at a $1 / 6$ ratio after $72 \mathrm{~h}$. To remove extracellular MF-I1, cells were treated with gentamicin $400 \mu \mathrm{g} / \mathrm{mL}$ and $0.005 \%$ Triton x-100 (both from Sigma-Aldrich, St. Louis, MO, USA) $2 \mathrm{~h}$ before harvesting the cells, as previously described [33]. Cell monolayers were washed twice in PBS, trypsinized, and washed 3 times in PBS to remove extracellular MF-I1. Cell culture supernatants were first centrifuged at $400 \times g$ to remove residual cells, and MF-I1 was then collected by centrifugation $\left(30 \mathrm{~min}\right.$ at $10,000 \times \mathrm{g}$ at $\left.4{ }^{\circ} \mathrm{C}\right)$. Parallel control cultures of MF-I1 growing in McCoy's 5A medium without HCT116 cells were harvested at the same time points. 


\subsection{Accession Numbers}

Nucleotide numbering of $r n h B 1$, dnaK, and $m g s 1$ RNAs is according to NCBI GenBank accession no, ATFG00000000 defining the complete genome of M. fermentans MF-I1. M. fermentans JER (accession no CP001995) was used for multiple alignment analyses.

\subsection{DNA and RNA Extraction}

Cellular DNA was extracted using PrepEase Genomic DNA Isolation Kits (USB Corporation, Cleveland, $\mathrm{OH}, \mathrm{USA}$ ), following instruction from the manufacturer. MF-I1 DNA from cellular supernatants was extracted using PureLink Viral RNA/DNA Mini Kit (ThermoFisher Scientific, Waltham, MA, USA). For RNA analyses, pellets from control MF-I1 axenic cultures grown overnight in 243 medium or for six days in McCoy's 5A medium without HCT116 cells were lysed in TRIzol (ThermoFisher Scientific, Waltham, MA, USA). RNA was extracted with chloroform, precipitated in isopropanol (both from Sigma-Aldrich, St. Louis, MO, USA), suspended in DEPC water, and used for cRT-PCR experiments. Similarly, HCT116 cultures infected with MF-I1 and uninfected controls were maintained in culture for 6 days and then harvested for RNA analyses using the TRIzol protocol.

\subsection{Analysis of Subcellular Fractions by SDS-PAGE and Immunoblot}

Subcellular fractionation was performed using the Qproteome cell compartment kit from Qiagen (\#37502, Qiagen, Hilden, Germany) and following the instructions from the manufacturer. For immunoblot analysis cytosol, membranes and nuclear compartments were isolated with the specific extraction buffer from the kit. After precipitation with acetone, the dry pellets were resuspended in RIPA buffer (ThermoFisher Scientific, Waltham, MA, USA) containing a protease inhibitor mixture (Sigma-Aldrich). $30 \mu \mathrm{g}$ of each lysate were resolved by electrophoresis on a $16 \%$ SDS-polyacrylamide gel using Tris-glycine-SDS running buffer (ThermoFisher Scientific, Waltham, MA, USA), electrotransferred to PVDF membrane (Bio-Rad, Hercules, CA, USA), by using Trans-Blot Turbo system (Bio-Rad, Hercules, CA, USA) and membranes were probed with antibodies specific for each fraction (all from Cell Signaling Technology, Danvers, MA, USA). Specifically, rabbit mAb antiglyceraldehyde-3-phosphate dehydrogenase (GAPDH) (cat. N 5174) was used as a marker for cytosol, rabbit mAb anti Syntaxin 6 (cat. N 2869) was used to label the membrane compartment and mouse mAb anti-Histone H3 (cat. N 3638) for the nucleus. RNA and DNA extractions from subcellular fractions were performed by using the TRIzol protocol (ThermoFisher Scientific, Waltham, MA, USA) or PrepEase Genomic DNA Isolation Kits (USB Corporation, Cleveland, OH, USA), respectively.

For Western blot analysis of DnaK protein, $70 \mu \mathrm{g}$ of cell lysate and $10 \mu \mathrm{g}$ of clarified supernatants were resolved by electrophoresis. PVDF membranes containing the transferred proteins were probed with anti-DnaK mouse mAb (Novus Biological, Littleton, $\mathrm{CO}, \mathrm{USA}$ ) and anti- $\beta$-actin rabbit mAb (Cell Signaling Technology, Danvers, MA, USA) antibodies. Blots were first incubated with a secondary HRP-conjugated antibody (Cell Signaling), then developed using an ECL chemiluminescent substrate kit (Genesee Scientific, San Diego, CA, USA), finally exposed and acquired using the ChemiDoc MP digital image system (Bio-Rad, Hercules, CA, USA).

\subsection{Cloning of MF-I1 dnaK}

The nucleotide sequence of $d n a K$ was obtained from the MF-I1 genomic sequence (Genbank accession number: ATFG00000000) and, along with a $5^{\prime}$ overhang of four nucleotides (CACC) to facilitate directional cloning, was synthesized (Blue Heron Biotechnology, Bothell, WA) and cloned into the pcDNA 3.1 Directional TOPO expression vector (ThermoFisher Scientific, Waltham, MA, USA) according to the manufacturer's recommendations.

\subsection{Quantitative PCR ( $q P C R$ ) for MF-I1 and Host Cell Genome Copy Numbers}

$10^{7}$ copies of pcDNA 3.1-dnaK plasmid were diluted in a 1:10 serial dilution five times in $40 \mathrm{ng}$ of uninfected HCT116 DNA and used as a standard template. The absolute 
copy numbers of MF-I1 in 40 ng DNA derived from infected cells were determined by comparison with a standard curve. For relative qPCR, intracellular MF-I1 isolate copy numbers were normalized to host genome copy numbers. HCT116 genomic DNA was extracted from uninfected cells and $100 \mathrm{ng}$ of DNA, corresponding to 20,000 cells, was diluted in a 1:10 serial dilution and utilized as standard template. The albumin gene (GenBank accession number: EF649953.1) was used as reference gene to normalize input genomic DNAs. qPCR was performed using an iQ5 thermocycler Real-Time PCR Detection System with an iQ SYBR Green Supermix (both from Bio-Rad, Hercules, CA, USA). The reaction conditions were: $15 \mathrm{~s}$ at $95^{\circ} \mathrm{C}$ followed by 35 cycles of denaturation for $15 \mathrm{~s}$ at $95{ }^{\circ} \mathrm{C}$ and annealing and extension for $60 \mathrm{~s}$ at $60^{\circ} \mathrm{C}$. Primers for the MF-I1 dnaK gene were: Forward, $5^{\prime}$-CCTGATGAAGTTGTTGCAATGG- $3^{\prime}$ and reverse, $5^{\prime}$-ACCAAGTGTAAGAGGTGTAACG-3'. Primers for host cell albumin were: forward, 5'GCTGTCATCTCTTGTGGGCTGT- $3^{\prime}$ and reverse, 5' $^{\prime}$-ACTCATGGGAGC TGCTGGTTC- $3^{\prime}$. The MF-I1 isolate copy number in 10,000 cells was determined from the ratio of MF-I1 copy number/(albumin copy number $\times 2$ ) $\times 10,000$ (the 2 -fold factor is because the albumin sequence is present at two copies per genome).

\subsection{Circularized RT-PCR (cRT-PCR) for Analysis of $5^{\prime}$ and $3^{\prime}$ Ends of MF-I1 Isolate $m R N A$}

Analysis of $5^{\prime}$ and $3^{\prime}$-ends of $M$. fermentans MF-I1 strain RNAs was as described previously [44] with minor changes. In brief, the $5^{\prime}$ cap was removed using $\mathrm{RppH}$ (New England Biolabs Inc., Ipswich, MA, USA) [45] in NEB Thermopol buffer $(1 \times=20 \mathrm{mM}$ Tris-HCl, $10 \mathrm{mM}$ (NH4)2SO4, $10 \mathrm{mM} \mathrm{KCl}, 2 \mathrm{mM} \mathrm{MgSO} 4,0.1 \%$ Triton ${ }^{\circledR} \mathrm{X}-100, \mathrm{pH}$ 8.8) for $1 \mathrm{~h}$ at $37^{\circ} \mathrm{C}$. Decapped RNA was extracted with phenol/chloroform and precipitated with $3 \mathrm{M}$ $\mathrm{NaOAc}, \mathrm{pH} 5.5$, and 2.5 volumes of ethanol. Circularization of $5 \mu \mathrm{g}$ of RNA was performed at $37^{\circ} \mathrm{C}$ for $1 \mathrm{hr}$ using T4 RNA ligase (Life Technologies Corporation, Grand Island, NY, USA), DNAse 1 (New England Biolabs Inc., Ipswich, MA, USA), and RNase inhibitor. C-RNA was extracted with phenol/chloroform and precipitated with $3 \mathrm{M} \mathrm{NaOAc}$, $\mathrm{pH} 5.5$, and 2.5 volumes of ethanol. Reverse transcription of circularized RNA was performed using primers R1 (see Figure S2 and Table S1) proximal to the origin of the MF-I1 RNA for $d n a K$ or the adjacent genes $r n h B 1$ and $m g s 1$. Reverse transcription was performed for $1 \mathrm{~h}$ at $55^{\circ} \mathrm{C}$ in $25 \mu \mathrm{L}$ using Superscript ${ }^{\mathrm{TM}}$ III Reverse Transcriptase with DTT 0.1M, dNTPs 10mM, and RNaseOut (all from ThermoFisher Scientific, Waltham, MA, USA). Enzymes were inactivated at $70{ }^{\circ} \mathrm{C}(15 \mathrm{~min}) .2 .5 \mu \mathrm{L}$ of the cRT reaction were used for the sequential PCR 1 reaction, with gene specific primers $\mathrm{R} 2$ (internal to $\mathrm{R} 1$ primer used for the RT reaction), and F1 proximal to the end of the gene (Table S1). PCR used AccuPrime ${ }^{\mathrm{TM}}$ Taq DNA Polymerase High Fidelity (ThermoFisher Scientific, Waltham, MA, USA) with an initial denaturation at $94{ }^{\circ} \mathrm{C}$ for $3 \mathrm{~min}$. cDNA was denatured at $94^{\circ} \mathrm{C}$ for $30 \mathrm{~s}$, annealed at $58^{\circ} \mathrm{C}$ for $30 \mathrm{~s}$, and elongated at $68^{\circ} \mathrm{C}$ for $1 \mathrm{~min}$. An elongation step of $10 \mathrm{~min}$ followed the 30 cycles of PCR. The PCR product was purified from a $1 \%$ agarose gel (ThermoFisher Scientific, Waltham, MA, USA) using the Qiagen gel purification Kit and eluted in $15 \mu \mathrm{L}$ vol. water. A second nested PCR was performed to guarantee the specificity of the reaction by using internal primers R2 and F2 (Table S1). The same protocol used for PCR 1 was used for PCR 2 reactions and the products purified in 1\% agarose. Purified PCR 2 product was eluted in $15 \mu \mathrm{L}$ volume and A-Tailed for $20 \mathrm{~min}$ at $70{ }^{\circ} \mathrm{C}$ with Taq DNA Polymerase and $0.2 \mathrm{mM}$ dATP (both from ThermoFisher Scientific, Waltham, MA, USA). The product was cloned into the T/A pGEM-T Easy Vector (Promega Corporation, Madison, WI, USA) following the manufacturer's instructions. Clones were subsequently selected and grown overnight. Plasmid DNA was isolated using Qiagen mini-prep kits and the insert sequenced by the Biopolymer/Genomics Core Facility at the University of Maryland, School of Medicine.

To analyze dnaK mRNA length, circularized RT-PCR was performed using the same protocol used for analyses of $5^{\prime}$ and $3^{\prime}$-ends of MF-I1 isolate mRNA. However, the dnaK primers were positioned in the center of the dnaK gene (see Figure S2 and Table S2). 


\subsection{Sequence Analyses}

We used the RNIE [46] program in sensitive mode to predict hairpins in MF-I1 isolate dnaK RNA and the web server: http:/ / www.softberry.com/berry.phtml?topic=bprom\& group =programs\&subgroup=gfindb (accessed on 14 January 2019) to predict internal promoters in MF-I1 dnaK DNA. Multiple sequence alignments were created using the MUSCLE program [47]. The consensus included a sequence logo in order to help visualize/identify rare mutations [48].

Statistical analyses. Statistical analyses used GraphPad Prism v 5.0. For categorical independent variables, differences between groups were assessed using the Student's $t$-test.

\section{Discussion}

Although mycoplasmas are generally considered extracellular pathogens, some species, including $M$. fermentans, can invade human cells and grow intracellularly [4-7]. In this regard, $M$. fermentans has been shown to fuse, invade, and reside in intracellular vacuoles $[9,49]$. Invasion of host cells may contribute to mycoplasma persistence, providing protection from the host immune response and antibiotic treatment, while at the same time releasing bacterial proteins inside the cell. We previously demonstrated that a chaperone protein, DnaK, from a M. fermentans subtype incognitus (MF-I1) isolated in our laboratory, binds and reduces functions of human poly-ADP ribose polymerase-1 (PARP1) and ubiquitin carboxyl-terminal hydrolase protein-10 (USP10), which are required for efficient DNA repair and proper p53 activities, respectively. Other bacteria associated with human cancers (M. pneumoniae, H. pylori, F. nucleatum, C. thrachomatis, and C. pneumoniae) have closely related DnaK proteins, indicating a potential common mechanism of cellular transformation [24]. DnaK is the major bacterial Heat Shock Protein 70 (Hsp70) [50] and is one of the most abundant constitutively expressed and stress inducible chaperones in bacteria [22]. As a molecular chaperone, it prevents protein misfolding and aggregation, ensuring proteome integrity [50]. The expression of bacterial heat shock genes is efficiently controlled at the transcriptional level by both positive [51] and negative mechanisms [37]. However, little is known about the levels and localization of dnaK RNA expression in bacterial particles upon cellular invasion, especially during the reduced levels of bacterial replication leading to chronic infection. By measuring intracellular viable bacterial particles and correlating them with $d n a K$ RNA and DnaK protein expression, we demonstrated that expression of $d n a K$ is continuous and elevated even after MF-I1 reached a steady-state levels inside the cells. In contrast, the amount of extracellular viable bacteria increased logarithmically, likely due in part to nutrient factors released by the host cells $[34,35]$. Further confirming this hypothesis, MF-I1 growth in cell-free, in axenic culture showed a significantly reduced replication rate.

By analyzing dnaK RNA using cRT-PCR and sequencing we demonstrated that the gene is expressed as a monocistronic mRNA, and identified the regulatory element CIRCE in the $5^{\prime}$ region and a Rho-independent hairpin terminator in the $3^{\prime}$ region. In addition, multiple sequence alignments revealed extensive variation in MF-I1 dnaK transcript length compared to the expected mRNA size. Notably, while the $3^{\prime}$-terminus was frequently complete and included the terminal hairpin region, most of the transcripts were truncated at the $5^{\prime}$-end. In particular, the alignment of $d n a K$ transcripts presented a staircase-like pattern. Based on our data and the literature $[40,52,53]$, it is likely that $5^{\prime}$-end truncated dnaK mRNA sequences result from an RNase-mediated degradation process. RNA decay is a critical mechanism for regulating gene expression in bacteria. Bacterial mRNA is degraded rapidly, with an average half-life of $2.0 \mathrm{~min}$ or less [54], and our analysis of RNA length likely showed multiple intermediates of this process. We hypothesize that decay is more frequent at the $5^{\prime}$-end because the $3^{\prime}$-end is protected by hairpin termination.

Bacteria have evolved complex mechanisms to survive under conditions of limited nutrients, and these responses affect gene expression and regulation [55-57]. Bacteria growth rates vary depending upon the type or amount of available nutrients, and many other growth-rate dependent parameters (such as gene and plasmid copy numbers, the abun- 
dance of RNA polymerases and ribosomes) also affect gene expression [58]. However, while the gene copy number per bacteria is growth rate dependent [59], the degradation rate of mRNA appears to be rather independent of growth rate [52], and in E. coli is attributed to autoregulation of RNase E [53]. Regulation of $d n a K$ expression is more complex, since it is also affected by growth rate dependence on concentrations of regulatory factors, and further studies are required to understand dnaK expression under different growth conditions.

Our data show that $5^{\prime}$-end truncated $d n a K$ mRNAs were dominant in infected eukaryotic cells and in 243 growth medium, as compared to $5^{\prime}$-end dnaK mRNAs from free bacterial grown in McCoy's 5A medium. A likely explanation is that the abundance of $5^{\prime}$-end truncated transcripts results in a more rapid RNA turnover within the context of eukaryotic cell infection. This in turn would represent an advantageous nutrient rich environment for the parasitic life mode of mycoplasma.

We also show that the full-length protein is expressed, as demonstrated by cRTPCR identification of complete $5^{\prime}$-end transcripts containing the ATG start codon and Western blot analysis. However, we also observed other truncated dnaK mRNA in infected eukaryotic cells, and the significance of these forms is not clear. Regarding the gene regulation, we found three putative dnaK internal promoters, and showed that few of the $d n a K$ mRNAs identified by cRT-PCR had the promoters localized in the origin of the $5^{\prime}$-end truncated sequences, suggesting that some of the $5^{\prime}$-end truncated transcripts may be initiated from internal promoters. We could not rule out that $d n a K$ transcription utilizes an alternative internal promoter/s and that therefore shorter forms of $d n a K$ protein could be expressed. However, we did not observe any shorter protein in our Western blot assays. This could mean that either the shorter proteins are expressed at levels below detection, or that our monoclonal antibody is not able to detect them.

Overall, our data indicate that elevated expression of bacterial dnaK RNA and DnaK protein is present even when intracellular bacteria reach a replicative steady state of growth. Given the ability of bacteria to secrete DnaK $[27,28]$, this would indicate that over time, the protein present in the intracellular compartments [24] could affect important cellular pathways. To this regard, in our previous paper we described the effect of DnaK in reducing activities of PARP1 and p53 [15,17,24,26]. Further studies are ongoing in our laboratory to identify other proteins bound to DnaK and the effect on their activity. Sequence analysis of $d n a K$ mRNA transcripts highlighted the presence of defective transcripts with frequent internal single point mutations, suggesting that the high M. fermentans MF-I1 RNA turnover could be not only a result of the environmental adjustment, but also of a faulty transcription.

In conclusion, our study advances the understanding of transcriptional regulation of the essential M. fermentans MF-I1 dnaK gene during invasion of eukaryotic cells and reveals considerable complexity. Identification of the major bacterial and host components that govern the process of RNA turnover is required to further elucidate the mechanisms of M. fermentans survival and dnaK expression inside eukaryotic cells.

Supplementary Materials: The following are available online at https: / www.mdpi.com/article/ 10.3390 /ijms22083885/s1.

Author Contributions: Conceptualization, S.C.; data curation, S.C., H.T., F.B., S.K. and D.Z.; formal analysis, S.C. and H.T.; funding acquisition, R.C.G. and D.Z.; investigation, S.C., F.B., S.K. and D.Z.; methodology, S.C. and D.Z.; supervision, S.C., M.R., R.C.G. and D.Z.; visualization, F.B.; writingoriginal draft, S.C. and D.Z.; writing-review and editing, S.C., H.T., F.B., S.K., F.C., M.R., R.C.G. and D.Z. All authors have read and agreed to the published version of the manuscript.

Funding: This research received no external funding.

Data Availability Statement: Data is contained within the article or supplementary material. The whole genome sequence of Mycoplasma fermentans strain MF-I1 has been deposited at NCBI GenBank under the accession number ATFG00000000.

Conflicts of Interest: The authors declare no potential conflicts of interest. 


\author{
Abbreviations \\ MF-I1 Mycoplasma fermentans-IHV-substrain 1 \\ PCR Polymerase Chain Reaction \\ PARP1 Poly (ADP-Ribose) Polymerase-1 \\ USP10 Ubiquitin carboxyl-terminal hydrolase 10 \\ CFU Colony Forming Units
}

\title{
References
}

1. Warren, J.R.; Marshall, B. Unidentified curved bacilli on gastric epithelium in active chronic gastritis. Lancet 1983, 1, $1273-1275$.

2. Buti, L.; Spooner, E.; Van der Veen, A.G.; Rappuoli, R.; Covacci, A.; Ploegh, H.L. Helicobacter pylori cytotoxin-associated gene A (CagA) subverts the apoptosis-stimulating protein of p53 (ASPP2) tumor suppressor pathway of the host. Proc. Natl. Acad. Sci. USA 2011, 108, 9238-9243. [CrossRef] [PubMed]

3. Razin, S.; Yogev, D.; Naot, Y. Molecular biology and pathogenicity of mycoplasmas. Microbiol. Mol. Biol. Rev. 1998, 62, 1094-1156. [CrossRef] [PubMed]

4. Yavlovich, A.; Katzenell, A.; Tarshis, M.; Higazi, A.A.; Rottem, S. Mycoplasma fermentans binds to and invades HeLa cells: Involvement of plasminogen and urokinase. Infect Immun. 2004, 72, 5004-5011. [CrossRef]

5. Lo, S.C.; Hayes, M.M.; Kotani, H.; Pierce, P.F.; Wear, D.J.; Newton, P.B., 3rd; Tully, J.G.; Shih, J.W. Adhesion onto and invasion into mammalian cells by mycoplasma penetrans: A newly isolated mycoplasma from patients with AIDS. Mod. Pathol. 1993, 6, 276-280.

6. $\quad$ Baseman, J.B.; Lange, M.; Criscimagna, N.L.; Giron, J.A.; Thomas, C.A. Interplay between mycoplasmas and host target cells. Microb. Pathog. 1995, 19, 105-116. [CrossRef]

7. Hegde, S.; Hegde, S.; Spergser, J.; Brunthaler, R.; Rosengarten, R.; Chopra-Dewasthaly, R. In vitro and in vivo cell invasion and systemic spreading of Mycoplasma agalactiae in the sheep infection model. Int. J. Med Microbiol. IJMM 2014, 304, $1024-1031$. [CrossRef] [PubMed]

8. Nunoya, T.; Omori, T.; Tomioka, H.; Umeda, F.; Suzuki, T.; Uetsuka, K. Intracellular Localization of Mycoplasma bovis in the Bronchiolar Epithelium of Experimentally Infected Calves. J. Comp. Pathol. 2020, 176, 14-18. [CrossRef] [PubMed]

9. Taylor-Robinson, D.; Davies, H.A.; Sarathchandra, P.; Furr, P.M. Intracellular location of mycoplasmas in cultured cells demonstrated by immunocytochemistry and electron microscopy. Int. J. Exp. Pathol. 1991, 72, 705-714.

10. Helaine, S.; Thompson, J.A.; Watson, K.G.; Liu, M.; Boyle, C.; Holden, D.W. Dynamics of intracellular bacterial replication at the single cell level. Proc. Natl. Acad. Sci. USA 2010, 107, 3746-3751. [CrossRef]

11. Steele-Mortimer, O. The Salmonella-containing vacuole: Moving with the times. Curr. Opin. Microbiol. 2008, 11, 38-45. [CrossRef] [PubMed]

12. Malik-Kale, P.; Winfree, S.; Steele-Mortimer, O. The bimodal lifestyle of intracellular Salmonella in epithelial cells: Replication in the cytosol obscures defects in vacuolar replication. PLoS ONE 2012, 7, e38732. [CrossRef] [PubMed]

13. Ribet, D.; Cossart, P. How bacterial pathogens colonize their hosts and invade deeper tissues. Microbes Infect. 2015, 17, 173-183. [CrossRef] [PubMed]

14. Benedetti, F.; Curreli, S.; Gallo, R.C.; Zella, D. Tampering of Viruses and Bacteria with Host DNA Repair: Implications for Cellular Transformation. Cancers 2021, 13, 241. [CrossRef]

15. Ainsworth, J.G.; Easterbrook, P.J.; Clarke, J.; Gilroy, C.B.; Taylor-Robinson, D. An association of disseminated Mycoplasma fermentans in HIV-1 positive patients with non-Hodgkin's lymphoma. Int. J. Std Aids 2001, 12, 499-504. [CrossRef]

16. Barykova, Y.A.; Logunov, D.Y.; Shmarov, M.M.; Vinarov, A.Z.; Fiev, D.N.; Vinarova, N.A.; Rakovskaya, I.V.; Baker, P.S.; Shyshynova, I.; Stephenson, A.J.; et al. Association of Mycoplasma hominis infection with prostate cancer. Oncotarget 2011, 2, 289-297. [CrossRef]

17. Henrich, B.; Rumming, M.; Sczyrba, A.; Velleuer, E.; Dietrich, R.; Gerlach, W.; Gombert, M.; Rahn, S.; Stoye, J.; Borkhardt, A.; et al. Mycoplasma salivarium as a Dominant Coloniser of Fanconi Anaemia Associated Oral Carcinoma. PLoS ONE 2014, 9, e92297. [CrossRef]

18. Jiang, S.; Zhang, S.; Langenfeld, J.; Lo, S.-C.; Rogers, M.B. Mycoplasma infection transforms normal lung cells and induces bone morphogenetic protein 2 expression by post-transcriptional mechanisms. J. Cell. Biochem. 2008, 104, 580-594. [CrossRef]

19. Namiki, K.; Goodison, S.; Porvasnik, S.; Allan, R.W.; Iczkowski, K.A.; Urbanek, C.; Reyes, L.; Sakamoto, N.; Rosser, C.J. Persistent Exposure to Mycoplasma Induces Malignant Transformation of Human Prostate Cells. PLoS ONE 2009, 4, e6872. [CrossRef]

20. Zhang, S.; Tsai, S.; Lo, S.-C. Alteration of gene expression profiles during mycoplasma-induced malignant cell transformation. BMC Cancer 2006, 6, 116. [CrossRef]

21. Logunov, D.Y.; Scheblyakov, D.V.; Zubkova, O.V.; Shmarov, M.M.; Rakovskaya, I.V.; Gurova, K.V.; Tararova, N.D.; Burdelya, L.G.; Naroditsky, B.S.; Ginzburg, A.L.; et al. Mycoplasma infection suppresses p53, activates NF- $\mathrm{kB}$ and cooperates with oncogenic Ras in rodent fibroblast transformation. Oncogene 2008, 27, 4521-4531. [CrossRef] [PubMed]

22. Calloni, G.; Chen, T.; Schermann, S.M.; Chang, H.C.; Genevaux, P.; Agostini, F.; Tartaglia, G.G.; Hayer-Hartl, M.; Hartl, F.U. DnaK functions as a central hub in the E. coli chaperone network. Cell Rep. 2012, 1, 251-264. [CrossRef] 
23. Saibil, H. Chaperone machines for protein folding, unfolding and disaggregation. Nat. Rev. Mol. Cell Biol. 2013, 14, 630-642. [CrossRef] [PubMed]

24. Zella, D.; Curreli, S.; Benedetti, F.; Krishnan, S.; Cocchi, F.; Latinovic, O.S.; Denaro, F.; Romerio, F.; Djavani, M.; Charurat, M.E.; et al. Mycoplasma promotes malignant transformation in vivo, and its DnaK, a bacterial chaperone protein, has broad oncogenic properties. Proc. Natl. Acad. Sci. USA 2018, 115, E12005-E12014. [CrossRef]

25. Yuan, J.; Luo, K.; Zhang, L.; Cheville, J.C.; Lou, Z. USP10 Regulates p53 Localization and Stability by Deubiquitinating p53. Cell 2010, 140, 384-396. [CrossRef]

26. Benedetti, F.; Cocchi, F.; Latinovic, O.S.; Curreli, S.; Krishnan, S.; Munawwar, A.; Gallo, R.C.; Zella, D. Role of Mycoplasma Chaperone DnaK in Cellular Transformation. Int. J. Mol. Sci. 2020, 21, 1311. [CrossRef]

27. Costa, T.R.D.; Felisberto-Rodrigues, C.; Meir, A.; Prevost, M.S.; Redzej, A.; Trokter, M.; Waksman, G. Secretion systems in Gram-negative bacteria: Structural and mechanistic insights. Nat. Rev. Microbiol. 2015, 13, 343. [CrossRef]

28. Holland, I.B. Translocation of bacterial proteins-An overview. Biochim. Biophys. Acta BBA Mol. Cell Res. 2004, 1694, 5-16. [CrossRef] [PubMed]

29. Benedetti, F.; Krishnan, S.; Cocchi, F.; Tettelin, H.; Gallo, R.C.; Zella, D.; Curreli, S. Proteome analysis of Mycoplasma fermentans cultured under aerobic and anaerobic conditions. Transl. Med. Commun. 2019, 4, 15. [CrossRef]

30. Musatovova, O.; Dhandayuthapani, S.; Baseman, J.B. Transcriptional heat shock response in the smallest known self-replicating cell, Mycoplasma genitalium. J. Bacteriol. 2006, 188, 2845-2855. [CrossRef]

31. Perez-Rodriguez, R.; Fisher, A.C.; Perlmutter, J.D.; Hicks, M.G.; Chanal, A.; Santini, C.L.; Wu, L.F.; Palmer, T.; DeLisa, M.P. An essential role for the DnaK molecular chaperone in stabilizing over-expressed substrate proteins of the bacterial twin-arginine translocation pathway. J. Mol. Biol. 2007, 367, 715-730. [CrossRef] [PubMed]

32. Guisbert, E.; Herman, C.; Lu, C.Z.; Gross, C.A. A chaperone network controls the heat shock response in E. coli. Genes Dev. 2004, 18, 2812-2821. [CrossRef]

33. Andreev, J.; Borovsky, Z.; Rosenshine, I.; Rottem, S. Invasion of HeLa cells by Mycoplasma penetrans and the induction of tyrosine phosphorylation of a 145-kDa host cell protein. FEMS Microbiol. Lett. 1995, 132, 189-194. [CrossRef] [PubMed]

34. Blötz, C.; Stülke, J. Glycerol metabolism and its implication in virulence in Mycoplasma. FEMS Microbiol. Rev. 2017, 41, 640-652 [CrossRef] [PubMed]

35. Zhu, X.; Dordet-Frisoni, E.; Gillard, L.; Ba, A.; Hygonenq, M.-C.; Sagné, E.; Nouvel, L.X.; Maillard, R.; Assié, S.; Guo, A.; et al. Extracellular DNA: A Nutritional Trigger of Mycoplasma bovis Cytotoxicity. Front. Microbiol. 2019, 10, 2753. [CrossRef]

36. Chang, L.J.; Chen, W.H.; Minion, F.C.; Shiuan, D. Mycoplasmas regulate the expression of heat-shock protein genes through CIRCE-HrcA interactions. Biochem. Biophys. Res. Commun. 2008, 367, 213-218. [CrossRef] [PubMed]

37. Narberhaus, F. Negative regulation of bacterial heat shock genes. Mol. Microbiol. 1999, 31, 1-8. [CrossRef]

38. De Hoon, M.J.; Makita, Y.; Nakai, K.; Miyano, S. Prediction of transcriptional terminators in Bacillus subtilis and related species. PLoS Comput. Biol. 2005, 1, e25. [CrossRef]

39. Portnoy, V.; Schuster, G. Mycoplasma gallisepticum as the first analyzed bacterium in which RNA is not polyadenylated. FEMS Microbiol. Lett. 2008, 283, 97-103. [CrossRef]

40. Guell, M.; van Noort, V.; Yus, E.; Chen, W.H.; Leigh-Bell, J.; Michalodimitrakis, K.; Yamada, T.; Arumugam, M.; Doerks, T.; Kuhner, S.; et al. Transcriptome complexity in a genome-reduced bacterium. Science 2009, 326, 1268-1271. [CrossRef]

41. Carpousis, A.J. The Escherichia coli RNA degradosome: Structure, function and relationship in other ribonucleolytic multienzyme complexes. Biochem. Soc. Trans. 2002, 30, 150-155. [CrossRef]

42. Commichau, F.M.; Rothe, F.M.; Herzberg, C.; Wagner, E.; Hellwig, D.; Lehnik-Habrink, M.; Hammer, E.; Volker, U.; Stulke, J. Novel activities of glycolytic enzymes in Bacillus subtilis: Interactions with essential proteins involved in mRNA processing. Mol. Cell. Proteom. MCP 2009, 8, 1350-1360. [CrossRef] [PubMed]

43. Altschul, S.F.; Gish, W.; Miller, W.; Myers, E.W.; Lipman, D.J. Basic local alignment search tool. J. Mol. Biol. 1990, 215 , 403-410. [CrossRef]

44. Slomovic, S.; Schuster, G. Circularized RT-PCR (cRT-PCR): Analysis of the $5^{\prime}$ ends, $3^{\prime}$ ends, and poly(A) tails of RNA. Methods Enzymol. 2013, 530, 227-251. [CrossRef]

45. Song, M.G.; Bail, S.; Kiledjian, M. Multiple Nudix family proteins possess mRNA decapping activity. RNA 2013, 19, 390-399. [CrossRef] [PubMed]

46. Gardner, P.P.; Barquist, L.; Bateman, A.; Nawrocki, E.P.; Weinberg, Z. RNIE: Genome-wide prediction of bacterial intrinsic terminators. Nucleic Acids Res. 2011, 39, 5845-5852. [CrossRef] [PubMed]

47. Edgar, R.C. MUSCLE: Multiple sequence alignment with high accuracy and high throughput. Nucleic Acids Res. 2004, 32, 1792-1797. [CrossRef] [PubMed]

48. Waterhouse, A.M.; Procter, J.B.; Martin, D.M.; Clamp, M.; Barton, G.J. Jalview Version 2-a multiple sequence alignment editor and analysis workbench. Bioinformatics 2009, 25, 1189-1191. [CrossRef] [PubMed]

49. Dimitrov, D.S.; Franzoso, G.; Salman, M.; Blumenthal, R.; Tarshis, M.; Barile, M.F.; Rottem, S. Mycoplasma fermentans (Incognitus Strain) Cells Are Able to Fuse with T Lymphocytes. Clin. Infect. Dis. 1993, 17, S305-S308. [CrossRef]

50. Hartl, F.U.; Hayer-Hartl, M. Converging concepts of protein folding in vitro and in vivo. Nat. Struct. Mol. Biol. 2009, 16, 574-581. [CrossRef] 
51. Roncarati, D.; Scarlato, V. Regulation of heat-shock genes in bacteria: From signal sensing to gene expression output. FEMS Microbiol. Rev. 2017, 41, 549-574. [CrossRef]

52. Bernstein, J.A.; Khodursky, A.B.; Lin, P.H.; Lin-Chao, S.; Cohen, S.N. Global analysis of mRNA decay and abundance in Escherichia coli at single-gene resolution using two-color fluorescent DNA microarrays. Proc. Natl. Acad. Sci. USA 2002, 99, 9697-9702. [CrossRef]

53. Jain, C.; Deana, A.; Belasco, J.G. Consequences of RNase E scarcity in Escherichia coli. Mol. Microbiol. 2002, $43,1053-1064$. [CrossRef]

54. Hui, M.P.; Foley, P.L.; Belasco, J.G. Messenger RNA degradation in bacterial cells. Annu. Rev. Genet. 2014, 48, 537-559. [CrossRef]

55. Matin, A. The molecular basis of carbon-starvation-induced general resistance in Escherichia coli. Mol. Microbiol. 1991, 5, 3-10. [CrossRef]

56. Jin, D.J.; Cagliero, C.; Zhou, Y.N. Growth rate regulation in Escherichia coli. FEMS Microbiol. Rev. 2012, 36, 269-287. [CrossRef] [PubMed]

57. Klumpp, S.; Zhang, Z.; Hwa, T. Growth rate-dependent global effects on gene expression in bacteria. Cell 2009, 139, 1366-1375. [CrossRef] [PubMed]

58. Bremer, H.; Dennis, P.P. Modulation of Chemical Composition and Other Parameters of the Cell at Different Exponential Growth Rates. Ecosal Plus 2008, 3. [CrossRef] [PubMed]

59. Cooper, S.; Helmstetter, C.E. Chromosome replication and the division cycle of Escherichia coli Br. J. Mol. Biol. 1968, 31, 519-540. [CrossRef] 